\title{
Studia
}

\author{
Katarzyna Bagan-Kurluta ${ }^{\text {a) }}$ \\ (D) https://orcid.org/0000-0001-8551-6214
}

\section{Dobro dziecka w sprawach o uprowadzenie dziecka za granicę Zmiany w prawie i ich spodziewane skutki*}

\begin{abstract}
The international child abduction is regulated in the Hague Convention of 25 October 1980 on the Civil Aspects of International Child Abduction, in the Council Regulation (EC) No 2201/2003 of 27 November 2003 concerning jurisdiction and the recognition and enforcement of judgments in matrimonial matters and the matters of parental responsibility, repealing Regulation (EC) No 1347/2000 (Brussels II bis), and in the domestic law - in the Code of Civil Procedure. In the recent years the Regulation Brussels II bis was subject to review. As a result drawbacks were indicated and amendments have been proposed, in particular with a view of simplifying the procedures. The changes were triggered by the increasing number of cases in which one of the parents removes the child without a consent from the other. The Ministry of Justice does not provide any data on the amount of cases taking place in Poland. It is nevertheless certain that this amount has increased in comparison to previous years. Moreover, it is acknowledged that contrary to the Hague Convention and the EU Regulation, many children abducted by their parents are retained in Poland. The amendments to the Code of Civil Procedure seem to address this situation and streamline the process of the return of the children. The question remains: do the proposed amendments to the EU Regulation and those already enacted in the Code of Civil Procedure warrant to a sufficient degree that the welfare of a child — being one of the determinants of these regulations — is safeguarded?
\end{abstract}

Keywords: international child abduction - the Hague Child Abduction Convention Regulation Brussels II bis - unauthorized removal of a child - welfare of a child

a) Dr hab., Uniwersytet w Białymstoku.

* Tłem do przedstawionych rozważań jest zderzenie przekonania autorki o doskonałości połączenia międzynarodowych instrumentów dotyczących uprowadzenia dzieci za- 


\section{Wprowadzenie}

Sprawy o uprowadzenie dziecka za granicę do niedawna były przedmiotem regulacji Konwencji haskiej dotyczącej cywilnych aspektów uprowadzenia dziecka za granicę z dnia 25 października 1980 r., Rozporzadzenia Rady (WE) nr 2201/2003 z dnia 27 listopada 2003 r. dotyczącego jurysdykcji oraz uznawania i wykonywania orzeczeń w sprawach małżeńskich oraz w sprawach dotyczacych odpowiedzialności rodzicielskiej, uchylającego rozporządzenie (WE) nr 1347/2000 (Bruksela II bis) ${ }^{1}$ oraz na gruncie prawa wewnętrznego - przede wszystkim przepisów Kodeksu postępowania cywilnego $\mathrm{w}$ sprawach o odebranie osoby podlegajacej władzy rodzicielskiej lub pozostającej pod opieką z art. 598[1] — 598[14]. Jednak w ostatnich latach rozporządzenie było przedmiotem przeglądu. W jego następstwie określone zostały mankamenty regulacji, zaproponowano zmiany idace $\mathrm{w}$ kierunku znacznego usprawnienia postępowania i w efekcie przyjęto obecnie obowiązujące Rozporządzenie Rady (UE) 2019/1111 z dnia 25 czerwca 2019 r. w sprawie jurysdykcji, uznawania i wykonywania orzeczeń w sprawach małżenskich i w sprawach dotyczacych odpowiedzialności rodzicielskiej oraz w sprawie uprowadzenia dziecka za granicę ${ }^{2}$. Przyczynkiem do głębokiego przeglądu była rosnąca liczba spraw, w których jeden z rodziców wyjeżdża z dzieckiem z kraju stałego pobytu, bez zgody drugiego z nich. Na stronie internetowej Ministerstwa Sprawiedliwości nie sposób jest doszukać się informacji dotyczących ilości spraw prowadzonych w polskich sądach ${ }^{3}$, niemniej jednak na podstawie informacji medialnych i głosów praktyków można twierdzić, że ich liczba systematycznie rośnie ${ }^{4}$. N. V. Lowe i V. Stephens podają, że w 2003 r. do Polski wpłynęło jedynie 18 wniosków o rozpatrzenie sprawy w trybie konwencji haskiej, a już 67 w 2008 r. (wzrost o $272 \%)^{5}$. Przyjmuje się też, że wbrew założeniom Konwencji haskiej dotyczącej cy-

granicę w Unii Europejskiej (jako teoretyka) z jej doświadczeniami w sferze praktyki (jako eksperta krajowego w przeglądach stosowania rozporządzenia Bruksela II bis i adwokata).

${ }^{1}$ OJ L 338, 23.12.2003, p. 1—29, special edition in Polish: Chapter 19 Volume 006 P. 243-271, dalej zwane rozporządzeniem 2201/2003.

${ }^{2}$ OJ L 178, 2.7.2019, p. 1, dalej zwane rozporządzeniem 2019/1111.

${ }^{3} \mathrm{Na}$ archiwalnych stronach https://isws.ms.gov.pl/pl/baza-statystyczna/ dostępne sa jedyne szczątkowe dane dotyczące znikomej ilości spraw dotyczących uprowadzeń, w których zastosowano mediacje.

${ }^{4}$ Według wiceministra sprawiedliwości M. Wójcika w 2016 r. było ich 190, rok później już 268. Por.: https://wiadomosci.radiozet.pl/Polska/Rzad-bierze-sie-za-zwiekszenie-ochrony-polskich-dzieci.-Rosnie-liczba-spraw-o-uprowadzenie (dostęp 29/09/2019).

${ }^{5}$ N.V. Lowe, V. Stephens: Global Trends in the Operation of the 1980 Hague Abduction Convention. „Family Law Quarterly” 46, no. 1 (Spring 2012), s. 48. 
wilnych aspektów uprowadzenia dziecka za granicę z dnia 25 października 1980 r. $^{6}$ i rozporządzenia, w Polsce pozostawiało się zbyt wiele dzieci uprowadzanych przez rodziców - dotyczyło to około 70\% przypadków procedowanych przez polskie sady ${ }^{7}$. W świetle analiz przeprowadzonych w latach 2005/2006 i 2008, takich przypadków w skali globalnej było tylko $31 \%{ }^{8}$. Oznacza to, że w prawie $70 \%$ spraw nakazywano powrót dziecka do kraju, z którego zostało ono uprowadzone — dokładnie odwróconą relację procentową od istniejacej w Polsce.

Zastanawiającym wydaje się taki sam procentowy wynik spraw europejskich i globalnych, a więc takich, które wychodzą poza ramy Unii Europejskiej, przede wszystkim z racji na wieloletnie zaangażowanie tej ostatniej w ograniczenie liczby uprowadzeń i zwiększenie skuteczności instrumentów prawnych odnoszących się do nich. Według P. Beaumonta, L. Walker i J. Holliday wynika to z faktu, że niektóre państwa unijne maja znacznie mniejsze doświadczenia $\mathrm{w}$ stosowaniu konwencji haskiej niż inne - pozaeuropejskie (jako przykład posłużyła im Litwa, w której dopiero w 2015 r. nastapiła koncentracja spraw w rękach 12 sędziów, którzy już niebawem nabędą doświadczenie w orzekaniu w takich sprawach) ${ }^{9}$. Oznacza to, że konwencja haska jest globalnie stosowana równie skutecznie co w Unii Europejskiej, gdzie wprowadzono dodatkowy instrument, stanowiący niejako przedłużenie działania konwencji, co wprost wynika z 17. motywu preambuły rozporządzenia 2201/2003: w przypadkach bezprawnego uprowadzenia lub zatrzymania dziecka, powrót dziecka powinien nastąić bezzwłocznie, i w tym celu konwencja haska będzie nadal obowiązywać uzupełniona przepisami niniejszego rozporządzenia, w szczególności artykułu 11 (w obecnej wersji z motywu 40, a także 2: „zawiera [ono] przepisy uzupełniające Konwencję haska”, motywu 16 i 17).

Zmiany wprowadzone do polskiego Kodeksu postępowania cywilnego, jak można domniemywać, mają wpłynąć na poprawę sytuacji, a więc usprawnić proces odbierania dzieci i zminimalizować liczbę dzieci pozostawianych w kraju. Pozostaje pytanie: czy zmiany rozporządzenia i Kodeksu postępowania cywilnego w wystarczającym stopniu zapewnią

${ }^{6}$ Dz. U. z 1995 r, poz. 528 i Dz. U. z 1999 r., poz. 1085, dalej zwanej „konwencja haską".

7 73\% w 2003 r., 72\% w 2008 r., zob. N.V. Love, V. Stephens, op. cit., s. 56.

${ }^{8}$ K. Trimmings: Child Abduction within the European Union. Oxford, 2013, s. 90, N. Lowe, V. Stephens: op. cit., s. 61. Por. P. Beaumont, L. Walker, J. Holliday: Conflicts of EU Courts on Child Abduction: The reality of Article 11(6)-(8) Brussels IIa proceedings across the EU, s. 13: https://www.abdn.ac.uk/law/documents/CPIL_Working_Paper_No_2016_1.pdf (dostęp 28/09/2019).

${ }_{9}^{9}$ P. Beaumont, L. Walker, J. Holliday: Conflicts of EU Courts on Child Abduction, op. cit. s. 15. 
realizację dobra dziecka, które jest jednym z wyznaczników stosowania regulacji w nich zawartych? ${ }^{10}$

\section{Dobro dziecka jako wyznacznik postępowania w sprawach o uprowadzenie dziecka za granicę}

Z art. 65 rozporządzenia 2201/2003 wynika obowiązek Komisji Europejskiej przedstawiania Parlamentowi Europejskiemu, Radzie i Europejskiemu Komitetowi Ekonomiczno-Społecznemu sprawozdań z jego wykonania na podstawie informacji dostarczonych przez państwa członkowskie, w miarę potrzeby, z propozycjami zmian (pierwszego sprawozdania do dnia 1 stycznia 2012 r., następnych - co pięć kolejnych lat). W motywie 29 preambuły do tego rozporządzenia podkreślono, że dla celów jego sprawnego funkcjonowania Komisja powinna dokonać przeglądu

${ }^{10} \mathrm{O}$ złożoności problemów związanych z uprowadzeniami, przede wszystkim w kontekście przemocy w rodzinie (ale też dobra dziecka, ochrony interesów matek) świadczy obszerna literatura (między innymi D. Martiny: Internationale Kindesentführung und europäischer Menschenrechtsschutz - Kollision unterschiedlicher Ansätze. Max Planck Private Law Research Paper No. 16/16, M. H. Weiner: Intolerable Situations and Counsel for Children: Following Switzerland's Example in Hague Abduction Cases. 58 AM. U. L. REV. 335 (2008), D. Bozin: The Hague Child Abduction Convention's Grave Risk of Harm Exception: Traversing the Tightrope and Maintaining Balance between Comity and the Best Interests of the Child. „University of Tasmania Law Review”, 35 (1), s. 24-42, LIBE Commitee, Cross-border parental child abduction in the EU (Ed. Swiss Institute of Comparative Law, Lukas Heckendorn Urscheler, Ilaria Pretelli). EU Directorate-General for Internal Policies 2015, C.S. Bruch: 'The Unmet Needs of Domestic Violence Victims and Their Children in Hague Child Abduction Convention Cases'. (2004) 38(3) „Family Law Quarterly” 529; M. Kaye: Hague Convention and the Flight from Domestic Violence: How Women and Children are Being Returned by Coach and Four.(1999) 13(2) „International Journal of Law, Policy and the Family” 191; R. Ho egger: What if She Leaves - Domestic Violence Cases Under the Hague Convention and the Insufficiency of the Undertakings Remedy. (2003) 18(1) „Berkeley Women's Law Journal" 181; S. Christie: 'The 'Grave Risk' or 'Intolerable Situation' Defence in Cases of Domestic Violence Under the Hague Child Abduction Convention. (2013) 3(4) „FamilyLaw Review" 191; G. Moskowitz: The Hague Convention on International Child Abduction and the Grave Risk of Harm Exception. (2003) 41(4) „Family Court Review” 580) a także program The Protection of Abducting Mothers in Return Proceedings: Intersection between Domestic Violence and Parental Child Abduction, współfinansowany przez Komisję Europejska, realizowany przez University of Aberdeen, Ludwig Maximilians University of Munich i Milano-Bicocca University, zob. https://research.abdn.ac.uk/poam/ (dostęp: 13/01/2020). 
jego stosowania i zaproponować konieczne zmiany. W 2014 r. Komisja Europejska zajęła się oceną stosowania rozporządzenia. W przyjętym sprawozdaniu ${ }^{11}$, na podstawie danych z 2008 r., odniesiono się do skali problemów, a więc do wymiany 706 wniosków o wydanie dziecka między państwami członkowskimi, 52-procentowego wskaźnika powrotów z jednego państwa członkowskiego do drugiego i 15-procentowego wskaźnika rozstrzygania wniosków wymienionych między państwami w terminie 6 tygodni $^{12}$. Ponadto $\mathrm{w}$ sprawozdaniu wskazano wprost, że Trybunał Sprawiedliwości i Europejski Trybunał Praw Człowieka określiły w swoim orzecznictwie szereg zasad dotyczacych uprowadzenia dziecka za granicę, kierując się głównie dobrem dziecka. Pierwszy z nich — przede wszystkim zasadę, zgodnie z którą w rozporządzeniu dąży się do zapobiegania uprowadzaniu dziecka $\mathrm{z}$ jednego państwa członkowskiego do innego oraz do doprowadzenia do niezwłocznego powrotu dziecka, jeżeli dojdzie do jego uprowadzenia ${ }^{13}$. Drugi z trybunałów orzekł o obowiązku państw podjęcia odpowiedniego i skutecznego działania w celu zapewnienia powrotu dziecka, w przypadku ustalenia, że doszło do bezprawnego uprowadzenia dziecka. Brak podjęcia tego rodzaju działania stanowi, według ETPCz, naruszenie prawa do życia rodzinnego określonego w art. 8 Konwencji o ochronie praw człowieka i podstawowych wolności ${ }^{14}$. Mimo stanowczego w tej kwestii stanowiska, ETPCz w niektórych sprawach zdecydował jednak, że zapewnienie powrotu dziecka może stanowić naruszenie art. 8 wspomnianej konwencji — w szczególności, gdy wezwany sąd nie docenił wagi problemów, które dziecko prawdopodobnie doświadczyłoby w związku z powrotem do państwa pochodzenia, gdy nie dysponował on informacjami wystarczającymi do określenia, czy istniało ryzyko w rozumieniu art. 13 lit. b) konwencji haskiej lub gdy nie prze-

${ }^{11}$ Sprawozdanie Komisji dla Parlamentu Europejskiego, Rady i Europejskiego Komitetu Ekonomiczno-Społecznego w sprawie stosowania rozporządzenia Rady (WE) nr 2201/2003 dotyczącego jurysdykcji oraz uznawania i wykonywania orzeczeń w sprawach małżeńskich oraz w sprawach dotyczących odpowiedzialności rodzicielskiej, uchylającego rozporządzenie (WE) nr 1347/2000, Bruksela, dnia 15.4.2014 r., $\operatorname{COM}(2014) 225$ final, https://eur-lex.europa.eu/LexUriServ/LexUriServ.do?uri=COM: 2014:0225:FIN:PL:PDF (dostęp: 20/07/2019).

${ }^{12}$ Ibidem, s. 14-15. Oznacza to, że przynajmniej w obrocie prawnym między państwami UE nie znajdują potwierdzenia dane dotyczące powrotu dzieci.

${ }^{13}$ Ibidem, s. 14. Por. Sprawa C-195/08 PPU Rinau, Zb.Orz. 2008, s. I-05271, pkt 52.

${ }^{14}$ Por. Šneersone i Kampanella przeciwko Włochom (skarga nr 14737/09), pkt 85 ppkt (iv); Iglesias Gil i A.U.I. przeciwko Hiszpanii (skarga nr 56673/00); Ignaccolo-Zenide przeciwko Rumunii (skarga nr 31679/96), Maire przeciwko Portugalii (skarga nr 48206/99); PP przeciwko Polsce (skarga nr 8677/03) oraz Raw przeciwko Francji (skarga nr 10131/11). 
prowadził skutecznej oceny zarzutów skarżącego na mocy art. 13 lit. b) konwencji haskiej ${ }^{15}$.

Rozporządzenie (w obu wersjach) obejmuje swym zakresem sprawy dotyczące uprowadzenia dziecka za granicę, będąc, jak już wspomniano, niejako przedłużeniem i uzupełnieniem postanowień konwencji haskiej. Ma na celu w szczególności zniechęcanie do uprowadzania dzieci z jednego państwa członkowskiego do drugiego, a, w przypadku gdy do takiego uprowadzenia dojdzie - spowodowanie, by powrót dziecka nastąił niezwłocznie ${ }^{16}$. Konwencja haska została przyjęta w przekonaniu, że interes dziecka ma podstawowe znaczenie we wszystkich sprawach dotyczacych opieki nad nim oraz że należy chronić dziecko na płaszczyźnie międzynarodowej przed szkodliwymi skutkami wynikajacymi z bezprawnego uprowadzenia go lub zatrzymania, a także o konieczności ustalenia zasad postępowania w celu zagwarantowania niezwłocznego powrotu dziecka do państwa jego stałego pobytu oraz zapewnienia ochrony prawa do odwiedzin ${ }^{17}$. Znajduje to potwierdzenie $\mathrm{w}$ motywach rozporzadzenia 2201/2003: 12, 13 (pierwszeństwo najlepszego interesu dziecka w kwestiach jurysdykcyjnych) i 33, w którym wprost przyjęto zgodność rozporządzenia z prawami podstawowymi i stosowanie się w nim do zasad Karty Praw Podstawowych Unii Europejskiej, a także zapewnienie za jego pośrednictwem przestrzegania praw podstawowych dziecka zgodnie z art. 24 Karty Praw Podstawowych Unii Europejskiej ${ }^{18}$. Co prawda nie

${ }^{15}$ Sprawozdanie, op. cit., s. 14-15. Por. sprawy Šneersone i Kampanella przeciwko Włochom (skarga nr 14737/09), pkt 95; B przeciwko Belgii (skarga nr 4320/11), pkt 76; X przeciwko Łotwie (skarga nr 27853/09), pkt 119. Brzmienie art. 13 konwencji haskiej jest następujace: Bez względu na postanowienia artykułu poprzedzającego władza sądowa lub administracyjna państwa wezwanego nie jest obowiązana zarządzić wydanie dziecka, jeżeli osoba, instytucja lub organizacja sprzeciwiajacca się wydaniu dziecka wykaże, że: a) osoba, instytucja lub organizacja opiekująca się dzieckiem faktycznie nie wykonywała prawa do opieki w czasie uprowadzenia lub zatrzymania albo zgodziła sie lub później wyraziła zgodę na uprowadzenie lub zatrzymanie; lub b) istnieje poważne ryzyko, że powrót dziecka naraziłby je na szkode fizyczna lub psychiczna albo $w$ jakikolwiek inny sposób postawiłby je w sytuacji nie do zniesienia. Władza sądowa lub administracyjna może również odmówić zarządzenia powrotu dziecka, jeżeli stwierdzi, że dziecko sprzeciwia się powrotowi oraz że osiągnęło ono wiek i stopień dojrzałości, przy którym właściwe jest uwzględnienie jego opinii. Przy ocenie okoliczności określonych w niniejszym artykule władza sądowa lub administracyjna powinna brać pod uwagę informacje dotyczace sytuacji społecznej dziecka, dostarczone przez organ centralny lub inną właściwą władzę państwa miejsca stałego pobytu dziecka.

${ }^{16}$ Sprawa C-195/08 PPU Rinau, Zb.Orz. 2008, s. 52.

${ }^{17}$ Ibidem, s. 48.

${ }^{18} \mathrm{~W}$ kontekście odpowiedzialności rodzicielskiej w motywie 19 rozporządzenia 2019/1111 przyjęto, że każde odwołanie do dobra dziecka należy interpretować w świetle art. 24 Karty Praw Podstawowych Unii Europejskiej i w świetle Konwencji Narodów Zjednoczonych o prawach dziecka z dnia 20 listopada 1989 r. wdrożonych na mocy pra- 
do końca wiadomo o jakie konkretnie prawa dziecka chodziło ustawodawcy europejskiemu, jednak należy zgodzić się z poglądem o szerokim ujęciu praw dziecka $\mathrm{w}$ tym postanowieniu Karty, za czym przemawia jego stylistyka, a więc odniesienie do wszystkich działań dotyczacych dzieci bez zawężenia ich do określonej kategorii ${ }^{19}$. W postanowieniu wyszczególniono jedynie prawa dziecka do swobodnego wyrażania swoich poglądów i do utrzymywania stałego, osobistego związku i bezpośredniego kontaktu z obojgiem rodziców. Jednak dwukrotnie odniesiono się do dobra dziecka, nie zawężając konieczności jego realizacji do wskazanych sytuacji, działań czy praw, a wprost przeciwnie - nadając mu charakter zasady rządzącej każdym postępowaniem. A więc w ust. 1 przyjęto, że dzieci maja prawo do takiej ochrony i opieki, jaka jest konieczna dla ich dobra, aby uzupełnić regulację ustępem drugim, na mocy którego we wszystkich działaniach dotyczacych dzieci, zarówno podejmowanych przez władze publiczne, jak i instytucje prywatne, należy przede wszystkim uwzględnić najlepszy interes dziecka. Zgodzić się należy z poglądem, że w ujęciu art. 24 Karty prawa dziecka różnią się od pozostałych praw równościowych zawartych w tym dokumencie wymiarem realizacji ukierunkowanym na najwyższe dobro dziecka, czego nie wyartykułowano w odniesieniu do żadnego innego prawa, ani innej wartości ${ }^{20}$. Znaczenie dobra dziecka było wielokrotnie podnoszone w orzecznictwie, między innymi w sprawach przed ETPCz dotyczacych pogwałcenia prawa do poszanowania życia rodzinnego, jak to wspomniano w sprawozdaniu Komisji Europejskiej. Przykładowo w sprawie M.A. przeciwko Austrii ${ }^{21}$ Trybunał stwierdził, że: 1) oba instrumenty (konwencja haska i rozporządzenie 2201/2003) opierają się na filozofii, że we wszystkich decyzjach dotyczących dzieci, ich dobro powinno być najważniejsze $\left.{ }^{22}, 2\right)$ w procedo-

wa krajowego i procedury krajowej, aby dalej, także w kontekście spraw dotyczących uprowadzeń dzieci, odnieść się jedynie do kwestii wysłuchania dziecka: Możliwość swobodnego wyrażania przez dziecko swoich poglądów, przewidziana w art. 24 ust. 1 Karty i w art. 12 Konwencji ONZ o prawach dziecka, odgrywa ważną rolę w stosowaniu niniejszego rozporządzenia (motyw 39 ).

${ }^{19}$ A. Wróbel (red.): Karta Praw Podstawowych Unii Europejskiej. Komentarz. Warszawa 2013, art. 24, Legalis.

${ }^{20}$ Ibidem.

${ }^{21}$ Skarga nr 4097/13, wyrok 15 kwietnia 2015 r., https://hudoc.echr.coe.int/ eng\#\{,itemid”:[„001-150704”]\} (dostęp 28/09/2019). Trybunał uznał, że władze austriackie nie działały szybko, a dostępne ramy proceduralne nie ułatwiaja sprawnego i skutecznego przeprowadzenia procedury powrotu dziecka.. Skarżący, którym był ojciec dziecka uprowadzonego przez matkę z Włoch do Austrii, nie otrzymał skutecznej ochrony jego prawa do poszanowania życia rodzinnego, a co za tym idzie, nastąiło naruszenie art. 8 Europejskiej konwencji praw człowieka i podstawowych wolności.

${ }^{22}$ Por. także X przeciwko Łotwie, skarga nr 27853/09, wyrok 26 listopada 2013 r., https://hudoc.echr.coe.int/eng\#\{,itemid”:[“001-138992”]\} (dostęp 28/09/2019). 
waniu należy przede wszystkim uwzględnić dobro dziecka, a cele, jakimi sa zapobieganie uprowadzeniom i natychmiastowy powrót, odpowiadają swoistej koncepcji „najlepiej pojętego interesu dziecka”"23, 3) w sferze uprowadzenia dziecka za granice pozytywne obowiązki, o których mowa w art. 8 Europejskiej konwencji praw człowieka i podstawowych wolności nałożone na jej strony powinny być interpretowane w kontekście postanowień konwencji haskiej i Konwencji praw dziecka, w których przykłada się największą wagę do najlepiej pojętego interesu dziecka ${ }^{24}$.

\section{Zmiany regulacji prawnych w kontekście postulatu szybkości postępowania}

Zgodnie z informacjami zawartymi w propozycji zmiany rozporządzenia z końca czerwca 2016 r. $^{25}$, Komisja Europejska po przyjęciu sprawozdania z jego stosowania rozpoczęła konsultacje publiczne $\mathrm{w}$ odniesieniu do zaproponowanych przez nią zmian, w których uwzględniono także orzecznictwo, w tym 24 wyroki Europejskiego Trybunału Sprawiedliwości dotyczące wykładni rozporządzenia 2201/2003. W opinii Komisji do braku spodziewanej skuteczności rozporządzenia odnieść się należy w kontekście braku doprecyzowania czy termin 6 tygodni dotyczacy procedury powrotu dziecka odnosi się do całości postępowania, czy tylko do postępowania pierwszoinstancyjnego, braku ograniczenia liczby odwołań, które można wnieść od zarządzenia powrotu dziecka, braku wyspecjalizowanych sędziów zajmujacych się takimi sprawami, a w odniesieniu do uznawania orzeczeń $\mathrm{w}$ tej materii - do różnych przepisów odnoszących się do wysłuchania dziecka. ”Obecne przepisy skłaniają w szczególności te państwa członkowskie, których standardy w zakresie wysłuchania dziecka są bardziej rygorystyczne niż w państwie członkowskim, w którym wydano dane orzeczenie, do odmowy jego uznania

${ }^{23}$ Ibidem.

${ }^{24}$ Por. Ignaccolo-Zenide przeciw Rumunii, skarga nr 31679/96, wyrok 25 stycznia 2000 r, https://hudoc.echr.coe.int/eng\#\{,,itemid”:[„,001-58448”]\} (dostęp 28/09/2019), Neulinger i Shuruk przeciw Szwajcarii [GC], skarga nr 41615/07, wyrok 6 lipca 2010, https://hudoc.echr.coe.int/FRE\#\{,itemid”:[„,001-99817”]\} (dostęp 28/09/2019).

${ }^{25} \mathrm{COM}(2016) 411$ final, 2016/0190(CNS) Wniosek Rozporządzenie Rady w sprawie jurysdykcji, uznawania i wykonywania orzeczeń w sprawach małżeńskich i w sprawach dotyczących odpowiedzialności rodzicielskiej oraz w sprawie uprowadzenia dziecka za granicę (wersja przekształcona), \{SWD(2016) 207 final\}, \{SWD(2016) 208 final\}. 
i odmowy przyznania exequatur, jeżeli wysłuchanie dziecka nie spełnia ich własnych standardów. Ponadto znaczenie wysłuchania dzieci nie jest ogólnie wyeksponowane w rozporządzeniu w odniesieniu do wszystkich przypadków spraw dotyczących odpowiedzialności rodzicielskiej, lecz jedynie $\mathrm{w}$ odniesieniu do postępowania w sprawie powrotu dziecka. Jeżeli dane orzeczenie zostanie wydane bez wysłuchania dziecka, istnieje niebezpieczeństwo, że takie orzeczenie może nie uwzględniać w wystarczającym stopniu dobra dziecka" ${ }^{26}$. Wyniki badań opublikowanych w $2016 \mathrm{r}$. pokazuja, że w przypadkach uprowadzeń, dzieci były wysłuchane przez sąd tylko w $17 \%$ spraw $^{27}$.

W związku z powyższym, do proponowanego nowego tekstu rozporządzenia zostały wprowadzone postanowienia przewidujace: 1) ograniczenie czasu procedowania każdego z organów prowadzących postępowanie (organu centralnego, sądu pierwszej instancji oraz sądu odwoławczego) do sześciu tygodni, co łącznie przekłada się na termin maksymalnie 18 tygodni na zakończenie sprawy, 2) koncentrację jurysdykcji w sprawach uprowadzenia w określonej, ograniczonej liczbie sądów wyspecjalizowanych - ponieważ sędziowie procedujący $\mathrm{w}$ większej liczbie spraw nabywaja szczególnego doświadczenia ${ }^{28}$, 3) ograniczenie do jednego liczby odwołań, z dopuszczeniem tymczasowej wykonalności orzeczeń nieprawomocnych, 4) dokładne rozważenie dobra dziecka, w tym wysłuchanie każdego dziecka, które jest w stanie formułować poglądy ${ }^{29}$, ponieważ w opinii Komisji Europejskiej, wydanie decyzji bez niego może grozić tym, że nie będzie ona w wystarczającym stopniu uwzględniała dobra dziecka ${ }^{30}$. Wszyst-

${ }^{26}$ Ibidem.

${ }^{27}$ M. Drventic: New Trends in European Family Procedural Law, EU and Comparative Law Issues and Challenges. Series 1 (2017), s. 437 na podstawie raportu Conflicts of EU courts on child abduction: http://www.abdn.ac.uk/law/documents/Conflicts-ofEU_CourtsonChildAbductionCountry-Reports_25_May_(Final).pdf. i P. Beaumont, L. Walker, J. Holliday: Conflicts of EU Courts on Child Abduction, op. cit., s. 25.

${ }^{28}$ P. Beaumont, L. Walker, J. Holliday: Parental Responsibility and International Child Abduction in the proposed recast of Brussels IIa Regulation and the effect of Brexit on future child abduction proceedings. s. 3, https://www.abdn.ac.uk/law/documents/CPIL_Working_Paper_No_2016_6_revised.pdf (28/09/2019). Postulat ten był już wcześniej zgłaszany przez doktrynę.

${ }^{29}$ Ibidem.

${ }^{30}$ COM, 2016, 4: Commission Proposal for a Council Regulation on jurisdiction, the recognition and enforcement of decisions in matrimonial matters and the matters of parental responsibility, and on international child abduction (recast)' COM(2016) 411/2 http://ec.europa.eu/justice/civil/files/family-matters/brussels2_regulation_en.pdf (dostęp: 7/07/2016). Zob. P. Beaumont, L. Walker, J. Holliday: Parental Responsibility and International Child Abduction, op. cit., s. 6. 
kie powyższe propozycje Komisji zostały umieszczone w rozporządzeniu $2019 / 1111^{31}$.

W ramach toczacych się i już zakończonych postępowań dotyczących uprowadzeń dzieci za granicę, w kontekście celów rozporządzenia 2201/2003 i konwencji haskiej oraz przedstawionych przez Komisję Europejską propozycji zmian przyjętych w rozporządzeniu 2019/1111, umieścić można dwa modele procedowania. W modelu pierwszym, w którym nacisk położono na szybkie rozstrzygnięcie sprawy, dziecko powinno być $\mathrm{z}$ reguły wydane wnioskodawcy - z wyjątkiem sytuacji oczywiście patologicznych, a więc znęcania się nad nim przez rodzica, od którego zostało uprowadzone, jego alkoholizmu lub uzależnienia od innych substancji - szybko, bez badania rzeczywistych relacji rodzinnych i wpływu, jaki na sytuację dziecka będzie miało odesłanie do kraju, z którego zostało uprowadzone, bez wysłuchania dziecka. W modelu drugim dziecko powinno być wydane po przeprowadzeniu sprawnego postępowania mającego na celu ustalenie jaki wpływ na jego sytuację będzie miało odesłanie do kraju, z którego zostało uprowadzone, z uwzględnieniem dobra dziecka, jego opinii, bez przyjęcia a priori założenia o ograniczeniu pozostawiania dziecka w kraju, do którego zostało uprowadzone jedynie do sytuacji oczywiście patologicznych relacji rodzinnych. W modelach tych przeciwstawiono szybkość postępowania dobru dziecka, co zresztą nie powinno mieć miejsca $\mathrm{z}$ racji na manifestowana w obu aktach prawnych konieczność realizacji obu wartości, traktowanych jak zasady. Nie jest zresztą oczywiste czy szybkość postępowania w takich sprawach można określić mianem wartości lub zasady, czy nie ma ona zapobiec zaaklimatyzowaniu się dziecka w nowym otoczeniu i niejako sztucznemu rozluźnieniu lub nawet rozerwaniu więzów łączących je z drugim z rodziców — a przez to, czy nie należałoby określić jej mianem narzędzia realizacji dobra dziecka.

Na tym tle umieścić można hipotetyczną sprawę pani X, która przyjechała ze Szkocji do Polski ze swoim niespełna trzyletnim dzieckiem, nie uzyskawszy wcześniej na wyjazd dziecka zgody jego ojca, a swojego byłego partnera. Dziecko przez całe swoje życie mieszkało z matką, przez ostatni okres ponad roku wyłącznie z nią i z jej rodziną. Partner matki umiarkowanie uczestniczył w codziennym życiu dziecka, po rozstaniu pary jego zainteresowanie nim sprowadzało się do cotygodniowych kontaktów i niewielkich alimentów. Nie reagował na potrzeby dziecka,

${ }^{31}$ Co ciekawe, dobro dziecka może również być przeszkodą w wysłuchaniu dziecka, jak chyba należy rozumieć koncept wskazany w motywie 39 rozporządzenia 2019/1111: chociaż wysłuchanie jest prawem dziecka, nie może być ono traktowane jako bezwzględny obowiązek, ale musi być oceniane z uwzględnieniem dobra dziecka, na przykład $\mathrm{w}$ przypadkach zawarcia porozumienia między stronami. 
jego problemy zdrowotne były mu obojętne, nie wspierał matki dziecka w jego wychowaniu, nie decydował także o niczym co dotyczyło dziecka. Wiódł swoje życie, dodatkowo próbując ingerować w życie swojej byłej partnerki, doprowadzając do rozpadu jej kolejnego związku i szkalując jej rodzinę oraz ją samą przed znajomymi. Wiedział, że traktuje ona swój pobyt w Szkocji typowo zarobkowo i tymczasowo, a zatem, że będzie chciała wrócić do Polski razem z dzieckiem. Pani X po przyjeździe do Polski wniosła do sądu sprawy o ustalenie miejsca pobytu dziecka przy matce, o ograniczenie praw rodzicielskich ojca dziecka oraz o alimenty na dziecko. W międzyczasie jej były partner wystapił w Szkocji o zakazanie jej wyjazdu z dzieckiem ze Szkocji. Wydany został tam nakaz, na mocy którego powinna ona być zatrzymana na granicy, jednak okazał się spóźniony, ponieważ pani X zdążyła już wyjechać z dzieckiem ze Szkocji. Po trzech miesiacach od ich wyjazdu, do sądu w Polsce wpłynął wniosek o wydanie dziecka w trybie konwencji haskiej. W związku z tym sąd, który ledwo rozpoczał procedowanie we wniesionych przez pania X sprawach, był zobowiązany je zawiesić, co też uczynił. Sprawa w pierwszej instancji trwała 5 miesięcy, zakończyła się wyrokiem nakazującym wydanie dziecka ojcu w terminie miesiąca. Sąd nie uwzględnił kwestionowanego przez pozwana faktycznego wykonywania władzy rodzicielskiej przez ojca dziecka, ani nie dopatrzył się możliwości wystąpienia skutków nie do zniesienia dla dziecka, zakładając, że dziecko powróci do Szkocji samo, ponieważ jego matce grozi tam za uprowadzenie dziecka kara pozbawienia wolności. Nie zdecydował się też na przeprowadzenie badania dziecka przez biegłego psychologa, mimo że opinia kuratora była zdecydowanie przychylna matce. Sprawa apelacyjna zakończyła się rok po przyjeździe dziecka do Polski. Ojciec dziecka w tym czasie ani razu nie próbował się z nim skontaktować, nie pojawił się także na żadnej rozprawie, oprócz apelacyjnej - mimo że był w tym czasie dwukrotnie w Polsce. W międzyczasie starał się (zreszta bezskutecznie) odebrać dziecko matce, ponieważ orzeczenie I instancji, mimo że nieprawomocne, było wykonalne. W sprawie apelacyjnej uczestniczył prokurator, który poparł stanowisko matki dziecka oraz Rzecznik Praw Dziecka, który także poparł jej stanowisko, dodatkowo wnioskując o przeprowadzenie dowodów z opinii biegłego psychologa oraz zbadania jaka odpowiedzialność grozi pani X za uprowadzenie dziecka w Szkocji. Matka dziecka przedstawiła prywatna opinię biegłego psychologa wskazującą na to, że ich rozłączenie spowoduje destrukcyjne skutki dla psychiki i rozwoju dziecka. Sąd drugiej instancji oddalił wnioski dowodowe Rzecznika Praw Obywatelskich, nie uwzględnił przedstawionej opinii psychologicznej i wyrokując 
o wydaniu dziecka ojcu nie dopatrzył się nieuwzględnienia dobra dziecka $\mathrm{w}$ trakcie postępowania.

Przedstawiony stan faktyczny ilustruje typowa sprawę, w której nie było zachowań świadczacych o patologicznych zachowaniach partnerów — rodziców dziecka, w której konflikt między nimi wpłynął na ich postępowanie względem wspólnego dziecka. Podkreślić należy, że ojciec dziecka nie wykazywał żadnego zainteresowania swoim dzieckiem w trakcie jego nieobecności w Szkocji, a dziecko było niezmiernie związane z matką i jej rodziną, z którą spędziło całe swoje życie. Na podkreślenie zasługuje również fakt, że sprawa toczyła się przez rok, w tym czasie nie przeprowadzono badań psychologicznych dziecka, ani też nie wysłuchano go w obecności psychologa. Żaden z sądów nie analizował problemu dla realizacji dobra dziecka zasadniczego: jakie konsekwencje uprowadzenia dziecka poniesie jego matka, a więc czy uniemożliwią one faktyczny kontakt z dzieckiem (ponieważ matka będzie odbywała karę pozbawienia wolności), czy staną się przeszkodą w orzeczeniu o ustaleniu opieki nad dzieckiem i pozostawieniu go przy matce, czy też nawet staną się przeszkodą w orzeczeniu o jej kontaktach z dzieckiem. Nie można zapomnieć o tym, że w świetle polskiego prawa karnego, sankcja za uprowadzenie dziecka, poza kara pozbawienia wolności, może być zakaz kontaktów i zbliżania się do dziecka przez czas wskazany przez sąd. Jeżeli przyjąć, że takie rozwiązania sa praktykowane w innych państwach (np. w hipotetycznym przypadku Szkocji), możliwe jest, że polski sąd realizując dobro dziecka i odsyłając je do państwa, z którego zostało uprowadzone albo dopuści aby dziecko pojechało tam bez matki, albo aby pozostawało tam bez kontaktów z matką. Oznacza to, że konsekwencją orzeczenia jest pozbawienie dziecka możliwości wychowywania się i przebywania z obojgiem rodziców, na co panaceum miał być właśnie połaczony mechanizm stosowania konwencji haskiej i rozporządzenia. W świetle postanowienia SN z dnia 1 grudnia 1999 r., oddzielenie od matki w zasadzie nie może stać na przeszkodzie powrotowi bezprawnie uprowadzonego dziecka do państwa miejsca jego stałego pobytu ${ }^{32}$. Czy nie wynika $\mathrm{z}$ tego, że w rzeczywistości wspomniany mechanizm nie ma służyć realizacji dobra dziecka, ale napiętnowaniu określonych zachowań jego rodziców, czyli wywożenia dziecka za granicę bez zgody jego drugiego rodzica, bez względu na okoliczności?

Wracając do kwestii powyżej wskazanych modeli procedowania, w tej hipotetycznej sprawie nie osiągnięto żadnego z celów, którym modele te zostały podporządkowane, a więc ani szybkiego procedowania zakończonego szybkim wydaniem orzeczenia (trwało ono rok), ani realizacji do-

${ }^{32}$ I CKN 992/99, OSNC 2000/6/111. 
bra dziecka (ponieważ pominięto kwestię rodzaju relacji łączącej dziecko z matka, możliwość jej definitywnego zerwania, długotrwałość sytuacji, w której znalazło się dziecko, brak zainteresowania dzieckiem ze strony ojca, a w końcu - możliwość oceny odniesienia się do wszystkich tych kwestii przez samo dziecko). W opinii Sądu Najwyższego zasady szybkości (pilności) postępowania o wydanie dziecka oraz zasada dobra dziecka „pozostają ze sobą w związku, który można ująć w wyjściowym założeniu, że nakaz możliwie szybkiego (niezwłocznego) wydania dziecka bezprawnie uprowadzonego służy jego dobru. Z tego względu silny nacisk na szybkość postępowania kładą zarówno Konwencja haska (preambuła, art. 2, 11 zdanie pierwsze i art. 12 zdanie pierwsze), jak i rozporzadzenie, wymaga tego także Konwencja praw dziecka (art. 11). Znajduje to zrozumienie i odzwierciedlenie również w judykaturze Sądu Najwyższego (por. np. postanowienie z dnia 1 grudnia 1999 r., I CKN 992/99, OSNC 2000, nr 6, poz. 111) i w orzecznictwie ETPCz, który w wyrokach w sprawach polskich z dnia 8 kwietnia 2008 r., 8677/03 i z dnia 2 listopada 2010 r., 31515, akcentował, że odpowiedniość zastosowanych środków jest oceniana przez pryzmat szybkości ich wdrożenia, gdyż upływ czasu może spowodować nieodwracalne skutki w relacjach dziecka z rodzicem. Praktyka dowodzi, że nie zawsze jest możliwe harmonijne połaczenie zasady szybkości postępowania z zasadą dobra dziecka i są sytuacje, w których trzeba przyznać pierwszeństwo jednej z nich. [...] Zasada ochrony dobra dziecka, przyjęta w Konwencji praw dziecka, Konwencji haskiej i innych aktach normatywnych krajowego porządku prawnego, w szczególności w Kodeksie rodzinnym i opiekuńczym, nakazuje przyjać, że dobro dziecka jest w każdym postępowaniu dotyczącym dziecka wartością pierwotną i nadrzędna, majaca podstawowe znaczenie we wszystkich sprawach dotyczących opieki nad nim. W orzecznictwie Sądu Najwyższego przyjmuje się, że kierowanie się tą zasadą stanowi bezwzględny obowiązek prawny, odnoszący się do każdej indywidualnej decyzji stosowania i wykładni prawa (por. np. uzasadnienia uchwał składu siedmiu sędziów z dnia 12 czerwca 1992 r., III CZP 48/92, OSNC 1992, nr 10, poz. 179 i z dnia 8 marca 2006 r., III CZP 98/05, OSNC 2006, nr 10, poz. 158, wyrok z dnia 8 czerwca 2000 r., V CKN 1237, oraz postanowienia z dnia 31 marca 1999 r., I CKN 23/99, OSNC 1999, nr 11, poz. 188, z dnia 7 lipca 2000 r., III CKN 796/00, i z dnia 12 grudnia 2000 r., V CKN $1805 / 00)^{33}$. Jak wynika z zaprezentowanego stanowiska, SN w przypadku konfliktu między zasadami przyznał pierwszeństwo zasadzie dobra dziecka, powołując się na olbrzymie jej znaczenie, a co wypadałoby tak-

${ }^{33}$ Uchwała SN z dnia 22 listopada 2017 r., III CZP 78/17, Legalis, Numer 1684119. 
że wskazać - powszechność traktowania jej jako pierwszoplanowy wyznacznik postępowania w sprawach dotyczacych dzieci.

W duchu reformy rozporządzenia w polskim postępowaniu cywilnym wprowadzone zostały dość zasadnicze zmiany, ze skutkiem od 28 sierpnia 2018 r. Wynikały one z przyjęcia Ustawy o wykonywaniu niektórych czynności organu centralnego $\mathrm{w}$ sprawach rodzinnych z zakresu obrotu prawnego na podstawie prawa Unii Europejskiej i umów międzynarodowych z dnia 26 stycznia 2018 r. ${ }^{34}$, która zakresem przedmiotowym obejmuje zasady i tryb postępowania polskiego organu centralnego, polskich sąów oraz innych polskich organów w sprawach rodzinnych z zakresu obrotu prawnego na podstawie prawa Unii Europejskiej i umów międzynarodowych, a także postępowania przed polskim organem centralnym, $\mathrm{w}$ sprawach uregulowanych czterema aktami prawnymi, w tym konwencja haska i rozporządzeniem ${ }^{35}$. W związu z tym powstała sytuacja, w której w krótkim marginesie czasowym sprawy dotyczace uprowadzenia dziecka za granice rozstrzygane w trybie konwencji haskiej były procedowane w dwóch trybach, tj. na podstawie dwóch odmiennych podstaw prawnych, a nawet, wziąwszy pod uwagę sprawy toczące się niejako $\mathrm{w}$ międzyczasie - w trzech.

W pierwszym wariancie sprawy wniesione przed 28 sierpnia $2018 \mathrm{r}$. były rozstrzygane $\mathrm{w}$ pierwszej instancji przez sądy rejonowe, które stosowały przepisy KPC dotyczące spraw o odebranie osoby podlegającej władzy rodzicielskiej lub pozostającej pod opieka. Na podstawie jeszcze niezmienionych przepisów, od orzeczenia sądu I instancji dopuszczalna była apelacja, ale jej złożenie nie wstrzymywało wykonalności wyroku pierwszoinstancyjnego. W związku z powyższym, możliwe było spowodowanie powrotu dziecka do kraju, z którego zostało uprowadzone jeszcze zanim orzeczenie stało się prawomocne, co wywoływało duże i zrozumiałe emocje. Ponadto pewne watpliwości budziło stosowanie w przypadku spraw wynikajacych z uprowadzeń dzieci za granicę przepisu art. 577 KPC, dopuszczającego zmianę przez sąd nawet prawomocnego postanowienia, jeżeli wymaga tego dobro osoby, której postępowanie dotyczy — będącego niejako wytrychem otwierającym sprawę na nowo, mimo res iudicata, gdy chodzi o dobro dziecka. Brak wprowadzenia do KPC instrumentów służących wzruszenia orzeczeń wydanych na podstawie konwencji ha-

${ }^{34}$ Dz. U. z 2018 r., poz. 416.

${ }^{35}$ Ponadto Europejską konwencją o uznawaniu i wykonywaniu orzeczeń dotyczących pieczy nad dzieckiem oraz o przywracaniu pieczy nad dzieckiem, sporządzona w Luksemburgu dnia 20 maja 1980 r., Dz. U. z 1996 r., poz. 134 i 135 oraz z 1997 r., poz. 196 i Konwencją o jurysdykcji, prawie właściwym, uznawaniu, wykonywaniu i współpracy w zakresie odpowiedzialności rodzicielskiej oraz środków ochrony dzieci, sporządzoną w Hadze dnia 19 października 1996 r., Dz. U. z 2010 r., poz. 1158. 
skiej świadczyć mogło o całkowitym wyłączeniu możliwości podważania takich rozstrzygnięć, tym samym dawać prymat postulatowi szybkości przywrócenia stanu rzeczy sprzed uprowadzenia lub zatrzymania dzie$\mathrm{cka}^{36}$, lub na odwrót - postulat szybkości postępowania nie oznaczał, że nie należy stosować przepisów krajowych regulujących postępowanie o odebranie dziecka, które toczyło się w trybie konwencji haskiej, ponadto brak było przepisu, zgodnie z którym postanowienie sądu nakazujące wydane dziecka w jej trybie nie mogło być zmienione ani uchylone ${ }^{37}$. Według G. Jędrejka wątpliwości dotyczące stosowania art. 577 KPC wynikały z dwóch kwestii: dwufazowości postępowań dotyczących odebrania dziecka oraz potencjalnego braku jurysdykcji krajowej ${ }^{38}$. Finalnie SN w uchwale z dnia 22 listopada 2017 r. stwierdził, że artykuł 577 KPC ma zastosowanie także do postanowień zarządzajacych wydanie dziecka na podstawie konwencji haskiej. Stanowisko swoje uzasadnił tym, że „wyłączenie jego stosowania wiązałoby się z nieuprawnionym założeniem, że w każdym wypadku pierwszorzędne znaczenie ma szybkie wydanie dziecka, utożsamiane $\mathrm{z}$ jego dobrem bez względu na okoliczności sprawy i ewentualne zmiany w położeniu dziecka. Szybkość postępowania, która jest pożądana i w założeniu ma służyć dobru dziecka rozumianemu jako ochrona przed szkodliwymi skutkami bezprawnego uprowadzenia lub zatrzymania, nie powinna być automatycznie utożsamiana z dobrem dziecka. Nie można a priori wykluczyć, że postulat szybkości postępowania będzie musiał ustąpić przed dobrem dziecka, ocenionym przy uwzględnieniu zmiany okoliczności, w świetle których wykonanie orzeczenia (powrót dziecka) narażałoby je na poważne ryzyko szkody fizycznej lub psychicznej. W takiej sytuacji sąd opiekuńczy, wyposażony w uprawnienie przewidziane $\mathrm{w}$ art. $577 \mathrm{KPC}$, może i powinien zareagować" ${ }^{39}$. Co więcej, odniósł się też do kwestii istnienia jurysdykcji krajowej, stwierdzenie braku której przez sąd mogło definitywnie zakończyć próbę wzruszenia zapadłego orzeczenia, przyjmując, że „utrzymuje się [ona] w sprawach o zmianę postanowienia zarządzającego wydanie dziecka, których przedmiotem nadal jest (pozostaje) wydanie dziecka i w których materialnoprawną podstawę orzeczenia stanowią przepisy konwencji haskiej

${ }^{36}$ T. Zembrzuski: Zmiana postanowienia o zarzqdzeniu powrotu dziecka wydanego na podstawie przepisów Konwencji haskiej. Zagadnienia prawne w praktyce SN. MOP 2018, Nr 7, s.360.

${ }^{37}$ G. Jędrejek: Zmiana postanowienia zarzqdzajacego powrót dziecka wydanego na podstawie Konwencji dotyczqcej cywilnych aspektów uprowadzenia dziecka za granice. MOP 2015, Nr 20, s. 1078.

${ }^{38}$ Ibidem, s. 1076.

${ }^{39}$ Uchwała SN z dnia 22 listopada 2017 r., III CZP 78/17, Legalis, Numer 1684119. Wcześniej także postanowienie SN z dnia 27 kwietnia 2017 r., II CNP 67/17, niepubl. 
i rozporządzenia, definiujące pojęcie bezprawności uprowadzenia (zatrzymania) dziecka oraz określające przesłanki nakazania powrotu dziecka lub i odmowy wydania dziecka. Za utrzymaniem jurysdykcji krajowego sądu opiekuńczego, który wydał prawomocne postanowienie, przemawia też to, że jeżeli dopuszcza się zmianę postanowienia dotyczącego wydania dziecka, to konsekwentnie należy orzeczenie w tym zakresie pozostawić temuż sądowi opiekuńczemu. Zmiana prawomocnego orzeczenia następuje co prawda w nowej sprawie, niebędącej kontynuacją postępowania, w którym zapadło to orzeczenie, ale sprawy te pozostają ze sobą w związku zarówno w warstwie faktycznej, jak i w zakresie tożsamej podstawy prawnej" ${ }^{40}$. Nie powstrzymało to dalszej krytyki. Z. Kubicka-Grupa krytycznie oceniając stanowisko SN wskazała, że „nie można postawić znaku równości pomiędzy stosowaniem - w wyjątkowych sytuacjach i dla dobra dziecka - art. $577 \mathrm{KPC}$ a dobrem dziecka stanowiacym zasadniczą wartość podlegająca ochronie na gruncie konwencji haskiej. [...] Przyjęcie w preambule konwencji haskiej zasady zabezpieczenia najwyższego interesu dziecka jest mylace. Powszechnie akceptuje się bowiem, że zasadniczy cel konwencji, jakim jest zapobieganie uprowadzeniu dziecka, jest aktualny i nie pozostaje $\mathrm{w}$ sprzeczności z podstawowymi prawami człowieka. Ponadto, zakres badania dobra dziecka przez sąd państwa, do którego dziecko zostało zabrane (sąd konwencyjny), jest znacznie węższy niż tradycyjny zakres tej oceny przy orzekaniu o pieczy nad dzieckiem"41. Oznacza to, że w związku ze stosowaniem przepisu zderzyły się dwa stanowiska, pierwsze dopuszczające sprzeczność pomiędzy konwencyjnymi zasadami szybkości postępowania i dobra dziecka, drugie - odmienne - zakładające istnienie harmonii między celem konwencji a podstawowymi prawami człowieka w ogólności (o ile jako podstawowe można traktować np. prawo do życia rodzinnego i prawa dziecka w ogólności, ale także odnosić ten termin do zasady dobra dziecka wynikającej z art. 3 Konwencji praw dziecka ${ }^{42}$ ). Drugiemu sprzyjało przyjęcie, że konwencja haska odzwierciedla tezę, że uprowadzenie dziecka jest a priori sprzeczne $\mathrm{z}$ jego dobrem, a zabiegi prowadzace do przywrócenia stanu sprzed uprowadzenia podyktowane sa chęcią ochrony praw dziecka i powinny być, czy też są, zgodne z jego dobrem ${ }^{43}$. Wydaje się jednak, że o ile można

${ }^{40}$ Uchwała SN z dnia 22 listopada 2017 r., III CZP 78/17, Legalis, Numer 1684119.

${ }^{41} \mathrm{Z}$. Kubicka-Grupa: Zmiana prawomocnego orzeczenia zarzqdzajacego powrót dziecka wydanego na podstawie postanowienia konwencji haskiej o cywilnych aspektach uprowadzenia dziecka za granice. Glosa do uchwaty SN z dnia 22 listopada 2017 r., III CZP 78/17, PPC 2018/3/391-398.

${ }^{42}$ Dz.U. z 1991 r., nr 120, poz. 526.

${ }^{43}$ T. Zembrzuski: op. cit., s. 359. Por. T. Świerczyński: Podstawowe zagadnienia Konwencji haskiej o cywilnych aspektach uprowadzenia dziecka za granicę. TPP 
się zgodzić ze stanowiskiem, że uprowadzenie dziecka jest postępowaniem nagannym, z reguły godzacym w dobro dziecka, to nie sposób bezrefleksyjnie stwierdzić, że każdy powrót dziecka do państwa zwykłego pobytu sprzed uprowadzenia będzie zgodny z jego dobrem.

W drugim wariancie, a więc na podstawie znowelizowanych przepisów KPC, sprawy wszczęte po 28 sierpnia 2018 r., rozstrzygane sa $\mathrm{w}$ pierwszej instancji przez sądy okręgowe mające siedzibę $\mathrm{w}$ miejscowościach stanowiących siedziby sądów apelacyjnych. W uzasadnieniu do projektu ustawy wprowadzajacej zmiany, oprócz oczywistego powodu, czyli przekazania spraw wyspecjalizowanym i doświadczonym w tej materii sędziom, wskazano inne, nie do końca przekonujące, okoliczności, jak: a) powierzenie takich spraw licznym sądom rejonowym, nie sprzyja szybkości postępowania, b) w obszarze działania sąów rejonowych często brak jest tłumacza przysięgłego danego języka obcego oraz wyspecjalizowanych pełnomocników z zakresu prawa rodzinnego, c) niewielka powtarzalność spraw w sąach powoduje brak specjalizacji sędziów, d) najlepiej rozwinięta infrastruktura komunikacyjna w siedzibach apelacji stanowi gwarancję dostępu do sądów ${ }^{4}$. Sądem odwoławczym stał się Sąd Apelacyjny w Warszawie, który orzekać powinien w terminie sześciu tygodni od dnia przedstawienia mu przez sąd pierwszej instancji akt sprawy wraz z apelacją. Sąd nakazuje powrót dziecka w terminie nieprzekraczającym dwóch tygodni od dnia uprawomocnienia się postanowienia. Postanowienie staje się skuteczne i wykonalne dopiero po uprawomocnieniu się, ponieważ „zmiana orzeczenia nakazującego powrót tej osoby, gdyby orzeczenie to zostało wykonane przed prawomocnym rozstrzygnięciem, jak wymaga tego aktualny stan prawny, mogłaby nie przynieść oczekiwanego skutku w postaci ponownego powrotu do Rzeczypospolitej Polskiej tej osoby"45. Przepisu art. 577 KPC nie stosuje się, „aby nie była możliwa ponowna ingerencja sądu w treść orzeczenia

Nr 1-2/2000, s. 87, L. Kuziak: Konwencja haska dotyczqca cywilnych aspektów uprowadzenia dziecka za granice $i$ postępowanie $w$ sprawach o powrót dziecka $w$ Polsce. „Rodzina i Prawo" Nr 2/2007, s. 67.

${ }^{44} \mathrm{~W}$ uzasadnieniu wskazano liczbę około 100 spraw rocznie dotąd rozpatrywanych przez sądy rejonowe w całym kraju, choć wydaje się, że liczba spraw została zaniżona. Ponadto odwołano się do przykładów zagranicznych rozwiązań, a mianowicie koncentracji takich spraw rozstrzyganych w I instancji w 1 sadzie na cały kraj (Czechy, Litwa, Szwecja, Węgry), 3 sądach (Wielka Brytania), 22 sądach (Niemcy), 27 sądów (Ukraina). Por. https://www.google.com/url?sa=t\&rct=j\&q=\&esrc=s\&source=web\&cd=4\&cad=rja\& uact=8\&ved=2ahUKEwid6cWzut_kAhUPIYsKHRZRC_kQFjADegQIAxAC\&url=https $\% 3 \mathrm{~A} \% 2 \mathrm{~F} \% 2 \mathrm{Fw} w$ w.senat.gov.pl\%2Fdownload\%2Fgfx\%2Fsenat $\% 2 \mathrm{Fpl} \% 2 \mathrm{Fsenatposiedz}$ eniatematy\%2F3948\%2Fdrukisejmowe\%2F1827.pdf\&usg=AOvVaw03vLK-VLjSWi7dl Xg6FNLY, s. 26-27 (dostęp: 19/09/2019).

${ }^{45}$ Ibidem, s. 28. 
stosownie do zmiany okoliczności, gdyż to orzeczenie nie dotyczy statusu dziecka z punktu widzenia wykonywania władzy rodzicielskiej, lecz służy przywróceniu uprzedniego stanu. Stosowanie tego przepisu nie jest więc uzasadnione celami tej konwencji. Ponadto po wydaniu prawomocnego orzeczenia, w praktyce wyłączona będzie w tych sprawach jurysdykcja polskiego sądu"46. W zamian za wyrażony expressis verbis zakaz stosowania art. $577 \mathrm{KPC}$, a w świetle cytowanego uzasadnienia, z racji na "range orzeczeń wydawanych w tych sprawach przez ich kontekst międzynarodowy" i zasadność kształtowania orzecznictwa przez Sąd Najwyższy, wprowadzono możliwość wniesienia skargi kasacyjnej ${ }^{47}$.

Odnośnie spraw, które trafiły do sądów niejako pomiędzy obowiązywaniem starych i nowych przepisów pojawiły się wątpliwości co do stosowania art. 577 KPC. Wynikały one z art. 31 ustawy o wykonywaniu niektórych czynności organu centralnego $\mathrm{w}$ sprawach rodzinnych z zakresu obrotu prawnego na podstawie prawa Unii Europejskiej i umów międzynarodowych, który nakazuje do spraw wszczętych i niezakończonych przed dniem wejścia w życie ustawy stosowanie dotychczasowych przepisów. Z jednej strony, wynikałoby z niego stosowanie pierwszego trybu, a więc dopuszczalność apelacji i zastosowania art. $577 \mathrm{KPC}$, bez możliwości wniesienia skargi kasacyjnej, z drugiej jednak strony, jeśli traktować sprawy wszczęte na podstawie art. $577 \mathrm{KPC}$ jako sprawy nowe (a więc nie takie, które zostały wszczęte i niezakończone przed dniem wejścia w życie ustawy, ponieważ zmiana lub uchylenie prawomocnego postanowienia następuje $\mathrm{w}$ nowej sprawie niestanowiącej kontynuacji postępowania, w którym wydano orzeczenie ${ }^{48}$ ), to niedopuszczalne stawało się stosowanie do nich dotychczasowych, a więc starych przepisów. W konsekwencji tego drugiego rozumowania, nie było możliwe stosowanie do nich przepisu art. 577 KPC (ponieważ na jego podstawie inicjowane było nowe postępowanie), ale także skargi kasacyjnej (ponieważ była to sprawa wszczęta przed wejściem w życie nowych przepisów, dopuszczających jej stosowanie). Wzbudziło to szereg wątpliwości i sprzeciw środowisk wspierających walkę rodziców, którzy uprowadzili dzieci do Polski ${ }^{49}$, ale także skutkowało wystąieniem Rzecznika Praw Dziecka

${ }^{46}$ Ibidem, s. $28-29$.

${ }^{47}$ Ibidem, s. 27. Ustawa ponadto wprowadzono rozwiązania, które w intencji ustawodawcy z pewnością maja przyspieszyć i usprawnić postępowanie: sporządzenie i doręczenie uzasadnienia postanowienia z urzędu, które sporządza się w terminie dwóch tygodni od dnia ogłoszenia, a doręcza uczestnikom postępowania i prokuratorowi, obowiązkowe zastępstwo uczestników postępowania przez adwokatów lub radców prawnych.

${ }^{48}$ T. Zembrzuski: Zmiana postanowienia o zarzadzeniu powrotu dziecka wydanego na podstawie przepisów Konwencji haskiej. Zagadnienia prawne w praktyce SN. MOP 2018, Nr 7, s. 360.

${ }^{49}$ Głównie matek, por. Apel matek: Oddajcie $\$ 577$ kpc, https://pantarey.org/oddajcie- 
do Ministra Sprawiedliwości o wyjaśnienie stanowiska resortu w kwestii interpretacji art. 31 ustawy. Rzecznik słusznie podnosił, że „w konsekwencji tych zmian legislacyjnych uczestnicy postępowań o wydanie dziecka w trybie konwencji haskiej, wszczętych przed 27 sierpnia 2018 r., moga stracić możliwość wszczęcia postępowania o zmianę prawomocnego postanowienia w trybie art. $577 \mathrm{KPC}$, jak i nie nabęda prawa do wniesienia skargi kasacyjnej od prawomocnego postanowienia. Zatem ich sytuacja prawna może być nie tylko zdecydowanie gorsza w stosunku do uczestników postępowań wszczętych po wejściu w życie ustawy, ale nadto może ona ulec znacznemu pogorszeniu w porównaniu do stanu sprzed 27 sierpnia 2018 r., kiedy to strony miały możliwość składania wniosków o zmianę prawomocnych postanowień w trybie art. $577 \mathrm{KPC}^{50}$. Hipotetyczni bohaterowie sprawy polsko-szkockiej podzielili losy uczestników innych postępowań, którzy często czuli niedosyt narzędzi walki o pozostanie ze swoim dzieckiem. W czym ich sytuacja byłaby lepsza, gdyby do hipotetycznego stanu faktycznego zastosowano nowe przepisy? Wydaje się, że odpowiedź na to pytanie odnaleźć można w motywach wprowadzenia zmian, a więc szybkość, sprawność, rzetelność gwarantowana doświadczeniem sędziów, jednak czy wszystkie te zmiany rzeczywiście dadzą gwarancję dbałości o dobro dziecka?

\section{Podsumowanie}

Wydaje się, że oczywistą przyczyną zmiany przepisów powinno być przyspieszenie postępowań, które, jak wynika to z postanowień konwencji haskiej, powinny być toczone sprawnie, a wyroki powinny zapadać szybko. Niewatpliwie jednak, tak postanowienia konwencji haskiej, jak i standardy dotyczące praw dziecka, ale również przepisy Kodeksu rodzinnego i opiekuńczego, KC, KPC nakazuja uwzględnienie, a nawet przyznanie priorytetu dobru dziecka. Czy zatem można mówić, że zmiana przepisów przyczyni się do większej realizacji tego dobra? I czy $\mathrm{w}$ międzyczasie ustawodawca nie wylał dziecka $\mathrm{z}$ kapiela, stawiając na zwiększenie szybkości postępowań? Czy można też mówić o sprzeczności

§577-kpc/(dostęp 23/09/2019).

${ }^{50} \mathrm{https}$ ///brpd.gov.pl/aktualnosci-wystapienia-generalne/niejednoznaczna-interpretacja-przepisow-nowej-ustawy (dostęp: 23/09/2019). 
między możliwością realizacji dobra dziecka a szybkim rozstrzygnięciem sprawy w takich przypadkach?

Problem szybkości postępowania, przy zachowaniu rzetelności zbadania sytuacji będącej przedmiotem sprawy, wydaje się do rozwiązania przy zastosowaniu nieco innej metody, niż przyjęta w przepisach zmieniajacych KPC. Zachowanie terminu 6 tygodni od wpłynięcia wniosku przez są I instancji wymaga, aby termin rozprawy został wyznaczony niezwłocznie, a nawet - natychmiast, a sprawa toczyła się nie w odstępach miesięcznych, ale $\mathrm{w}$ dniowych, przy założeniu, że możliwe będzie w tym czasie sporzadzenie raportu kuratorskiego oraz opinii psychologicznej na temat dziecka i skutków jego wydania (także bez towarzystwa rodzica, który je uprowadził). Nie można zakładać, że jedynie oczywiste okoliczności po stronie rodzica, od którego dziecko zostało uprowadzone, jak jego alkoholizm lub inne uzależnienie, znęcanie się nad dzieckiem i jego matka, stanowia przesłankę oddalenia wniosku. Wówczas całe postępowanie byłoby zbędne, sprowadzałoby się do formalnego wydania nakazu wydania dziecka. Sprawy będące konsekwencją uprowadzenia dziecka za granicę wynikaja z rozpadu związków rodziców, w których w dużej mierze rolę odgrywa ich wzajemny do siebie stosunek, często niemający wiele wspólnego z realizacja dobra dziecka. Niemniej jednak należy przyjąć, że życie dziecka w skłóconej rodzinie, między rodzicami posługującymi się nim jako instrumentem ich rozgrywek, nie ma nic wspólnego z realizacja dobra dziecka. Ponadto, szczególnie w realiach uprowadzenia dziecka do Polski, często rodzic pozostający za granica jest silniejszy ekonomicznie od uprowadzającego, a co za tym idzie - stać go na utrzymywanie regularnych kontaktów z dzieckiem, nawet bezpośrednich, wiążących się z przyjazdami do Polski.

Rozważając, co jest w najlepszym interesie dziecka, sądy powinny brać pod uwage także to, że uprowadzenie z kraju, w którym czyn ten stanowi przestępstwo, może stać się przyczynkiem do pozbawienia praw rodzicielskich uprowadzającego, ich ograniczenia, pozbawienia lub ograniczenia możliwości kontaktowania się z dzieckiem, w końcu — do odmowy ustalenia miejsca jego pobytu w miejscu zamieszkania tego rodzica, a nawet do odmowy orzeczenia pieczy dzielonej między rodziców. Jeżeli zatem więzy z rodzicem, od którego dziecko zostało uprowadzone, nie sa silne lub zostały rozerwane lub znacznie osłabione, to nakaz wydania dziecka może skutkować uniemożliwieniem dziecku kontaktów także z drugim z rodziców, ewentualnie ich ograniczeniem. Zarówno konwencja haska, jak i oba rozporządzenia wskazuja na uprowadzenie z kraju, a nie od rodzica, jednak w wielu przypadkach powrotu dziecka, będzie to powrót do drugiego rodzica. W tym kontekście postępowanie sądu nie powinno mieć na celu jedynie ustalenia kto jest winny — a co za tym idzie 
kto powinien ponieść karę za uprowadzenie dziecka, ponieważ może to pośrednio prowadzić także do bezzasadnego ukarania dziecka.

Reasumując, połączony mechanizm konwencji haskiej i rozporządzenia będzie dobrze funkcjonował, gdy postępowanie będzie na tyle szybkie, aby zapobiec możliwości zaaklimatyzowania się dziecka w nowym otoczeniu, ale tylko wtedy, gdy sąd zapewni, czy to na etapie orzekania o powrocie/pozostawieniu dziecka, czy na etapie orzekania w przedmiocie pobytu dziecka i pieczy nad nim, rzetelne zbadanie wszystkich okoliczności mających wpływ na realizację dobra dziecka i orzeknie zgodnie z nim, powstrzymujac się od piętnowania rodzica, który uprowadził dziecko. P. Beaumont, L. Walker, J. Holliday słusznie wskazuja, że wyrok $\mathrm{w}$ sprawie nie powinien być natychmiast wykonalny, a powinien podlegać kontroli z punktu widzenia praw człowieka ${ }^{51}$, czyli tak prawa do poszanowania życia rodzinnego, jak i szczególnych praw dziecka realizowanych w kontekście jego dobra.

${ }^{51}$ P. Beaumont, L. Walker, J. Holliday: Conflicts of EU Courts on Child Abduction, op. cit., s. 50 . 